\title{
Countering Al Qaeda, Hezbollah, and their Ideologies
}

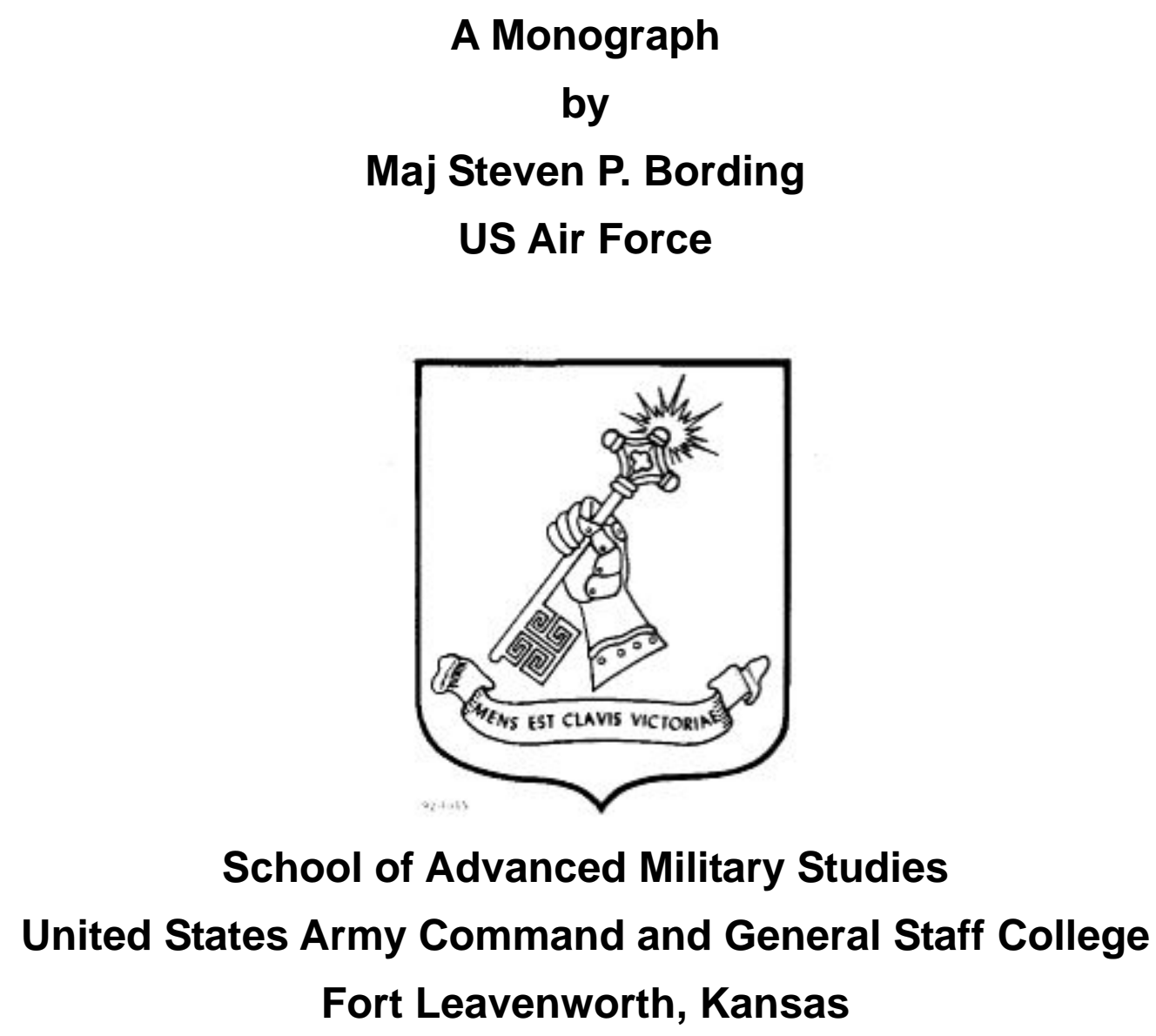

AY 2009 


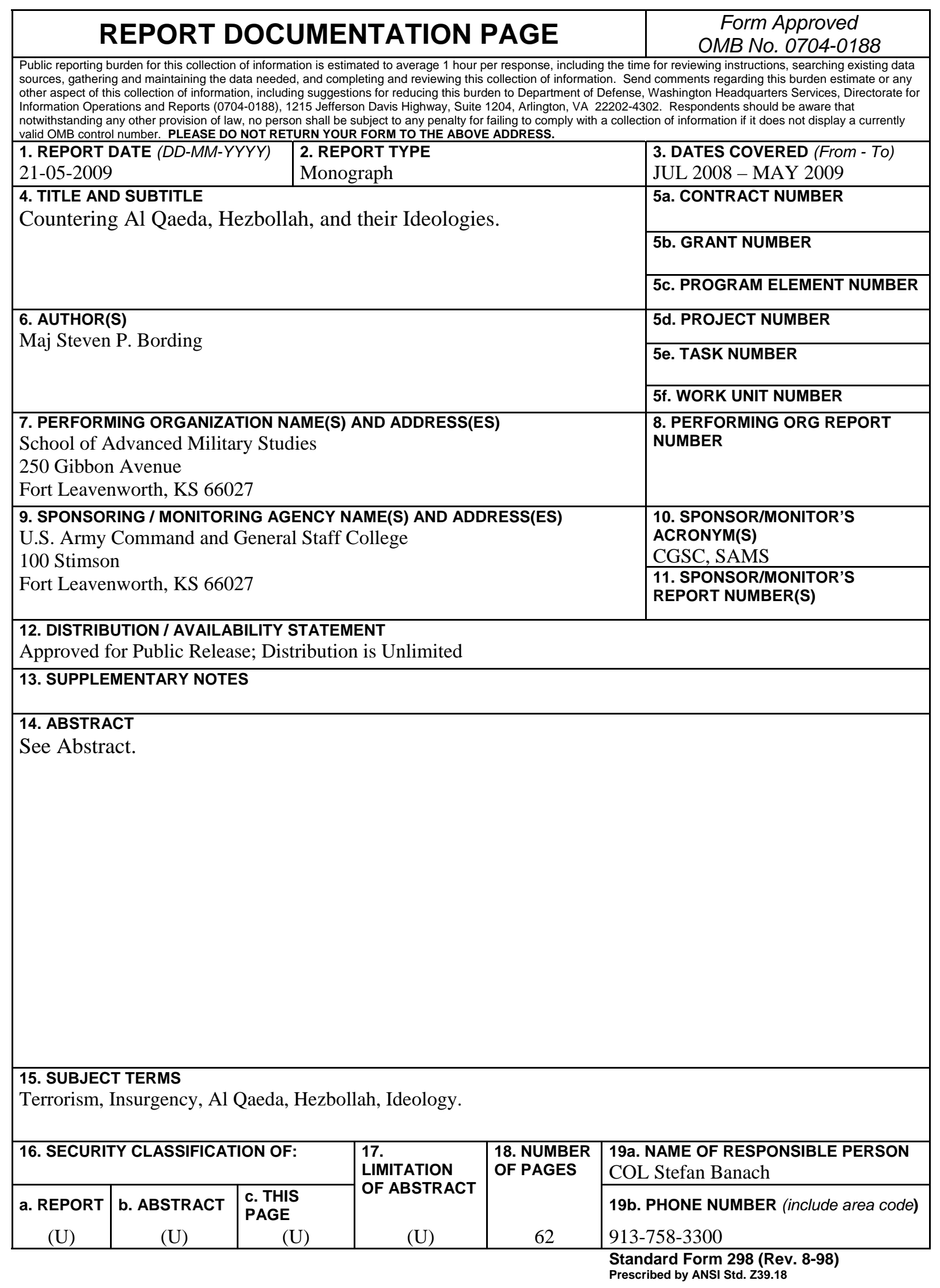




\section{SCHOOL OF ADVANCED MILITARY STUDIES MONOGRAPH APPROVAL}

Maj Steven P. Bording

Title of Monograph: Countering Al Qaeda, Hezbollah, and their Ideologies.

Approved by:

Daniel G. Cox, Ph.D.

Monograph Director

Director, School of Advanced

Military Studies

Director,

Robert F. Baumann, Ph.D.

Graduate Degree

Programs 


\section{ABSTRACT}

\section{COUNTERING AL QAEDA, HEZBOLLAH, AND THEIR IDEOLOGIES by Maj Steven P. Bording, US Air Force, 43 pages.}

While all warfare is an expression of politics, none is more pervasively so than irregular conflict. The irregular side, most probably employing a mixture of guerilla tactics and terrorism, will seek favorable political effect from several courses of action. Combating terrorism has become a global effort. Counterterrorism is a struggle of political wills, waged preeminently by the police and other security services, with the military acting in reserve. The most important weapon for the counter-terrorist is information. The war of ideas is crucial to today's terrorist, guerilla, and insurgent. Two of major terrorist organizations that pose the greatest potential threat to the United States are Al Qaeda and Hezbollah; both are motivated by two very powerful yet distinct ideologies.

Al Qaeda and Hezbollah may not share the same ideology, but ideology is a key component of why these groups undertake violent action. An ideology is a framework of ideas that describes a view of reality and a set of social and political actions that should be undertaken to change and improve the situation of a particular group. To succeed the insurgent or terrorist must win the war of ideas; the counter-terrorism forces cannot allow this to happen. Ideologies are thus difficult to combat using military forces, because ideas are extremely difficult to contain or destroy. Both Al Qaeda and Hezbollah thrive in the absence or weakness of governments and often operate in ungoverned regions, taking advantage of weak national control to smuggle weapons, money, and other resources. Unable to compete in a direct confrontation with regular, host nation forces, these groups use asymmetric tactics such as terrorism to engage their enemies and further their ideologies.

This paper furthers the understanding of disparate insurgencies through a comparative analysis of Al Qaeda and Hezbollah. The main goal is to show that the crucial divergence between Hezbollah and Al Qaeda allows for differing opportunities and a more nuanced US counter-terrorism approach when combating an amorphous, international, loosely tied, non-state movement versus a much more state sponsored, one could argue even state created, terror organization. Al Qaeda and Hezbollah were chosen because they pose the greatest threat to the United States and its global interests and they are at the forefront of US counter terror efforts. They have several notable similarities, yet still show significant and important divergence. Both groups are motivated by extreme ideologies; Sunni inspired Al Qaeda is motivated theologically by Salafi-jihadism, whereas Hezbollah's ideology is motivated by Iranian political objectives and a more inclusive stance on Islamic fundamentalism. Understanding the divergence between $\mathrm{Al}$ Qaeda and Hezbollah is crucial and will aid US counter-terrorism efforts. The main differences between Al Qaeda and Hezbollah will be addressed in detail within the specific cases studies in this paper. The unique global impact that these groups have on crime, terrorism, and insurgency will also be examined. Once dissimilarities are identified, prescriptions for United States counterterrorism strategy will be discussed. 


\section{TABLE OF CONTENTS}

ABSTRACT

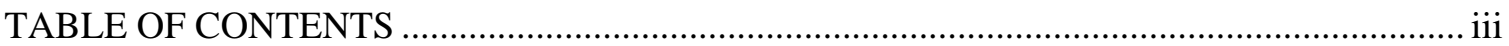

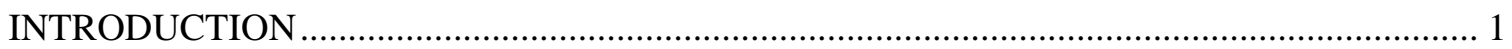

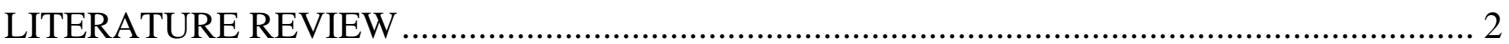

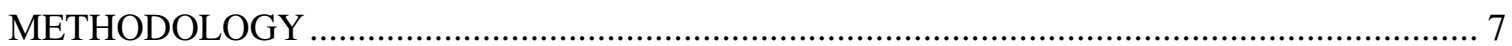

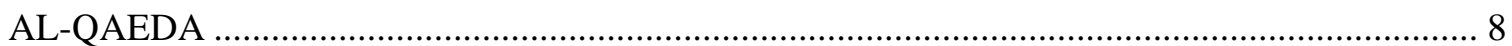

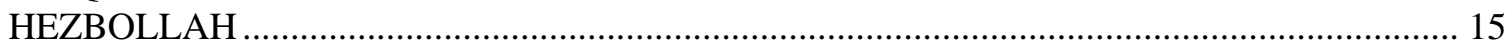

DIVERGENCE BETWEEN AL QAEDA AND HEZBOLLAH................................................ 23

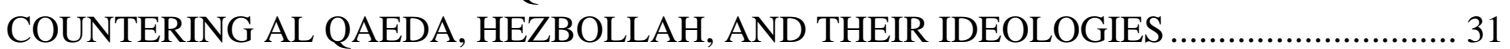

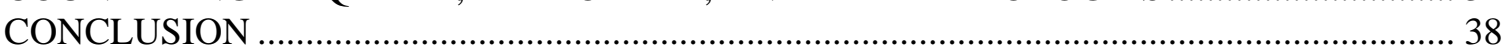

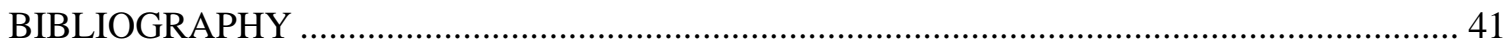




\section{INTRODUCTION}

This is another type of war new in its intensity, ancient in its origins-war by guerillas, subversives, insurgents, assassins; war by ambush instead of by combat; by infiltration, instead of aggression, seeking victory by eroding and exhausting the enemy instead of engaging him... a whole new kind of strategy, a wholly different kind of force, and therefore a new and wholly different kind of military training. ${ }^{1}$

The September 11, 2001 attacks against the World Trade Center in New York City and the Pentagon in Washington DC ushered in a new era of warfare. The United States (US) was now at war with a non-state actor, an enemy that would prove to be fundamentally different from anything the US had faced in several decades. This new enemy was not a traditional nation-state, regime, or alliance that US military forces had prepared and trained to fight. This new enemy was using terrorism and violence to advance their own unique political, theological, and ideological agendas. Nineteen days after the attacks, President George W. Bush addressed a joint session of Congress and stated, “Our War on terrorism begins with Al Qaeda, but does not end there. It will not end until every terrorist group of global reach has been found, stopped, and defeated.” ${ }^{2}$ With this statement, the Global War on Terror (GWOT) began. However, this unique new enemy will not be defeated on the open battlefield with traditional means and forces. The US must use its full spectrum of resources, continually reassess the threat, and adapt its tactics and methods as the enemy adapts its own.

\footnotetext{
${ }^{1}$ President John F. Kennedy, 1962.

${ }^{2}$ Sean N. Kalic, Combating a Modern Hydra: Al Qaeda and the Global War on Terrorism.1.
} 


\section{LITERATURE REVIEW}

"Insurgency, terrorism, and guerilla war are the manifestations of weak actors choosing asymmetric strategies against strong actors. Combining these three means to an end is the deadliest of options weak actors may choose.”3 In order to understand and counter terrorism and insurgency, one must first understand irregular warfare. The Department of Defense defines irregular warfare as “a violent struggle among state and non-state actors for legitimacy and influence over the relevant populations. It favors direct and asymmetric approaches, though it may employ the full range of military and other capabilities, in order to erode an adversary’s power, influence, and will.” ${ }^{4}$ Irregular warfare occurs between the regular forces of states and the irregular armed forces of non-state actors. Terrorism and guerilla warfare are both tactics of irregular warfare. "The regular soldier engaged in irregular warfare finds that the enemy has no obvious center of gravity, no capital city and probably no fixed lines of communication; looks identical to the civilian population and refuses to stand and fight, except at times and in places of his own choosing, or when it is trapped and has no choice." ${ }^{5}$ Insurgencies begin with irregular warfare, employing guerilla tactics and, often, terrorism.

Insurgency is not terrorism; terrorism is simply a tactic often used by guerillas or insurgents. Two of the seminal books on insurgencies and counterinsurgency (COIN) are David Galula’s “Counterinsurgency Warfare: Theory and Practice” and Bard O’Neill’s “Insurgency and Terrorism.” Both books provide systematic, straightforward approaches to understanding insurgencies and terrorist movements. O’Neill defines insurgency as a "struggle between a nonruling group and the ruling authorities in which the non-ruling group consciously uses political resources and violence to destroy, reformulate, or sustain the basis of legitimacy of one or more

\footnotetext{
${ }^{3}$ Joseph D. Celeski, Operationalizing COIN Joint Special Operations University. Sep, 2005.

${ }^{4}$ Irregular Warfare Joint Operating Concept. September 2007.

${ }^{5}$ Colin S. Gray, War, Peace and International Relations. (Routledge Publishing, New York, NY 2007), 248.
} 
aspects of politics.” ${ }^{6}$ He stresses that different forms of warfare including terrorism, guerilla warfare, and conventional warfare mark an insurgency. O’Neill defines terrorism as "the threat or use of physical coercion, primarily against non-combatants, especially civilians, to create fear in order to achieve various political objectives." ${ }^{7}$

Acknowledging that terrorism is a form of warfare often associated with insurgencies and not merely synonymous with insurgency is crucial to understanding insurgencies and terrorism. Galula defines an insurgency as “a protracted struggle conducted methodically, step by step, in order to attain specific intermediate objectives leading finally to the overthrow of the existing order.” ${ }^{8}$ Insurgencies are typically most successful when they have the support of a sympathetic populace, whom guerillas seek to win over by propaganda, reform, and often coercion. Insurgencies are often referred to as asymmetric, fought with guerilla tactics that use deception, ambush, and terror, as opposed to conventional force on force confrontation. O’Neill describes guerrilla warfare as "highly mobile, hit and run attacks by lightly to moderately armed groups that seek to harass the enemy and gradually erode his will and capability.”9

Colin Gray adds to the definition of terrorism when he states "terrorism is exemplary violence executed primarily for the purpose of inducing fear among the general public.” ${ }^{10} \mathrm{He}$ believes that terrorists are engaged in warfare designed to erode the will of the enemy, through demoralization and exhaustion. However, Gray believes that terrorism can occur in two forms, either as a strategic stand-alone technique of warfare or as an adjunct to guerilla operations. Terrorists cannot win militarily; they can only politically if the targeted government is coerced

\footnotetext{
${ }^{6}$ Bard E. O’Neill, Insurgency and Terrorism: From Revolution to Apocalypse. (Potomac Books, Inc., Washington D.C. 2005) 15.

${ }^{7}$ Ibid., 33.

${ }^{8}$ David Galula, Counterinsurgency Warfare: Theory and Practice. (Hailer Publishing, St Petersburg, FL. 2005) 4.

${ }^{9}$ O’Neill, 35.

${ }^{10}$ Gray, 256.
} 
and intimidated into offering political concessions or if the government overreacts in its retaliation and fuels an insurgency from an isolated terrorist campaign. ${ }^{11}$

"While all warfare is an expression of politics, none is more pervasively so than irregular conflict. The irregular side, most probably employing a mixture of guerilla tactics and terrorism, will seek favorable political effect from several courses of action.” ${ }^{12}$ Combating terrorism has become a global effort. Counterterrorism is a struggle of political wills, waged preeminently by the police and other security services, with the military acting in reserve. The most important weapon for the counter-terrorist is information. ${ }^{13}$ The war of ideas is crucial to today's terrorist, guerilla, and insurgent. Two of major terrorist organizations that pose the greatest potential threat to the US are Al Qaeda and Hezbollah; both are motivated by two very powerful yet distinct ideologies.

Al Qaeda and Hezbollah may not share the same ideology, but ideology is a key component of why these groups undertake violent action. An ideology is a framework of ideas that describes a view of reality and a set of social and political actions that should be undertaken to change and improve the situation of a particular group. ${ }^{14}$ To succeed the insurgent or terrorist must win the war of ideas; the counter-terrorism forces cannot allow this to happen. Ideologies are thus difficult to combat using military forces, because ideas are extremely difficult to contain or destroy. Both Al Qaeda and Hezbollah thrive in the absence or weakness of governments and often operate in ungoverned regions, taking advantage of weak national control to smuggle weapons, money, and other resources. Unable to compete in a direct confrontation with regular, host nation forces, these groups use asymmetric tactics such as terrorism to engage their enemies and further their ideologies.

\footnotetext{
${ }^{11}$ Ibid., 257.

12 Ibid.,254.

13 Ibid., 258.
} 
Ideology is a vital motivating force among Al Qaeda and Hezbollah. Their individualized ideologies allow them to recruit and amass popular support from populations that are anti-US or anti-Israel. These populations are receptive to the ideas that the West and Israel are stealing their lands and destroying their way of life with puppet governments and local surrogates. Al Qaeda has emerged as a new kind of insurgency, one that seeks to impose revolutionary change worldwide. They seek to transform the Islamic world and reorder its relationships with other regions and other cultures. Feeding on local grievances, Al Qaeda revolutionaries support causes they view as compatible with their own goals. This allows them to provision additional funds, volunteers, and sympathetic propaganda. They use terrorism, subversion, propaganda, open warfare, and suicide attacks to fuel their insurgency. Al Qaeda has leveraged their Salafi-Jihadist and extreme Sunni identity to create and enflame a global insurgency. For Al Qaeda, global armed jihad is the only way to restore Islam both politically and theologically.

"For years, terrorism has been perceived as a struggle between two adversaries: a group of people or an organization that is not a country versus a sovereign state. But in the second half of the twentieth century, various states have increasingly used terrorist organizations to promote their interests in the international arena." ${ }^{15}$ Hezbollah does not share the theological motivation that so propels Al Qaeda. Hezbollah’s ideology is driven by their political objectives and the political objectives of their state sponsors, Iran and Syria. "For Hezbollah, and even for Iran, the play for power in the region serves an ideological aim. Their influence over the Palestinians does not mean they want to spread Shiite Islam in Palestine. It's to confront Israel and the U.S. It is to spread resistance; that is the religion they want to spread.” ${ }^{16}$ State sponsorship of terrorism is mutually beneficial to both the state and the terrorist organization. State sponsorship of terrorist

${ }^{14}$ Christopher Pernin, Unfolding the Future of the Long War. (RAND Corporation, Santa Monica, CA. 2008), 125.

${ }^{15}$ Boaz Ganor. The Counter-Terrorism Puzzle. (Transaction Publishers, London,UK 2005), 79.

${ }^{16}$ Unfolding the Future of the Long War, 17. 
groups is "not a mindless act of fanatical or indiscriminate violence; rather it is a purposely targeted, deliberately calibrated method of pursuing specific objectives at acceptable cost.” ${ }^{17}$ State sponsorship permits the terrorist organizations to perpetrate attacks more easily as a means of spreading their ideology throughout the world.

"The war on terror at its most fundamental level goes to the war of ideas." ${ }^{18}$ Ideology is a powerful message that motivates and propels ordinary human beings into action. It frames organizational structure, both leadership and member's motivation, their recruitment and support, and shapes the group's strategies and tactics. Ideology, not poverty or illiteracy, is the key driver of politically motivated violence. In the post-9/11 environment, the centrality of ideology in terrorism has become increasingly evident. To counter terrorist ideology and to provide an alternative ideology, it is necessary to know its key ideologues, organizational structures, the evolving ideology, and its support community.

${ }^{17}$ Bruce Hoffman. Inside Terrorism. (Columbia University Press, New York, NY 2006), 267.

${ }^{18}$ RAND Corporation, Beyond Al Qaeda, (RAND Corporation Publication, Santa Monica, CA, 2006), xxiv. 


\section{METHODOLOGY}

This paper furthers the understanding of disparate insurgencies through a comparative analysis of Al Qaeda and Hezbollah. The "most similar systems comparative model” uncovers the main differences that exist between these two similar terror systems, Al Qaeda and Hezbollah. ${ }^{19}$ The main goal is to show that the crucial divergence between Hezbollah and Al Qaeda allows for differing opportunities and a more nuanced US counter-terrorism approach when combating an amorphous, international, loosely tied, non-state movement versus a much more state sponsored, one could argue even state created, terror organization. Al Qaeda and Hezbollah were chosen because they pose the greatest threat to the United States and its global interests and they are at the forefront of United States counter terror efforts. They have several notable similarities, yet still show significant and important divergence. Both groups are motivated by extreme ideologies; Sunni inspired Al Qaeda is motivated theologically by Salafi-jihadism, whereas Hezbollah’s ideology is motivated by Iranian political objectives and a more inclusive stance on Islamic fundamentalism. Understanding the divergence between Al Qaeda and Hezbollah is crucial and will aid US counter-terrorism efforts. The main differences between Al Qaeda and Hezbollah will be addressed in detail within the specific cases studies of Al Qaeda and Hezbollah in this paper. The unique global impact that these groups have on crime, terrorism, and insurgency will also be examined. Once dissimilarities are identified, prescriptions for United States counterterrorism strategy will be discussed.

${ }^{19}$ Gregory S. Mahler. Comparative Politics: An Institutional and Cross-National Approach. (Prentice Hall, Englewood Cliffs, NJ, 1995.), 6-7. 


\section{AL-QAEDA}

The jihad movement must make room for the Muslim nation to participate with it in the jihad for the sake of empowerment. The Muslim nation will not participate with the jihad movement unless the slogans of the mujahidin are understood by the masses. The one slogan that has been well understood by the nation and to which it has been responding for the past 50 years is the call for jihad against Israel. In addition to this slogan, the Muslim nation is geared against the US presence. The Muslim nation has responded favorably to the call for the jihad against the Americans. The jihad movement moved to the center of the leadership of the Muslim nation when it adopted the slogan of liberating the nation from its external enemies. Striking at the United States would force the Americans to personally wage the battle against the Muslims, which means that the battle will turn into a clear-cut jihad against infidels. ${ }^{20}$

Roughly translated, Al Qaeda means base or foundation; it is the pedestal that supports the column. The term first appeared in Afghanistan and referred to the most extreme elements of Islamic radicals fighting against Soviet occupation. In 1987, Abdallah Azzam, the chief ideologue of the non-Afghan militants drawn to fight alongside the mujahedeen used the word 'al-qaeda' to describe the role he envisioned for the most committed volunteers once the Soviets had withdrawn from Afghanistan in the following writing:

Every principle needs a vanguard to carry it forward and to put up with heavy tasks and enormous sacrifices. There is no ideology, neither earthly nor heavenly, that does not require... a vanguard that gives everything it possesses in order to achieve victory...It carries the flag along the sheer, endless and difficult path until it reaches its destination in the reality of life, since Allah has destined that it should make it and manifests itself. This vanguard constitutes the al-qaeda al-sulbah (strong foundation) for the expected society. ${ }^{21}$

Azzam saw Al Qaeda as a base, a base composed of individuals that were committed to the cause, the cause to serve as a revolutionary vanguard to the strong.

When the Soviet Union's war in Afghanistan ended, Osama bin Laden established a small militant group of a dozen of his closest associates in the western Pakistani frontier city of

\footnotetext{
${ }^{20}$ Jason Burke, Al Qaeda: The True Story of Radical Islam. (I.B. Tauris \& Co. New York, NY,
} 2006). 22.

${ }^{21}$ Ibid., 2. 
Peshawar. Since the Soviets had been defeated, bin Laden hoped to create an international army of Islamic extremists to defend Muslims from future oppression. Despite the unity that came from fighting the infidel invaders, national and ethnic divisions and competition from other radical Islamic groups plagued his group. Further, despite many challenges in his goal of internationalizing his struggle, he was able to provide a single focus for many of these different groups. From 1996 to 2001, Al Qaeda was able to provide its members with training, money, munitions, and safe haven; the Al Qaeda phenomenon of modern Islamic militancy had begun.

By the time the second US airliner crashed into the World Trade Center on September 11, 2001, Al Qaeda had arrived on the world stage. Al Qaeda is comprised of three core elements: a hardcore component, a network of co-opted groups, and most importantly, its ideology. ${ }^{22}$ In the few years leading up to the 9/11 attacks, bin Laden was able to attract and retain hundreds of the world's pre-eminent militants whom had the key skills and expertise bin Laden needed. Many of these militants were veterans of the war against the Soviets in Afghanistan, the wars in Bosnia and Chechnya as well as Algeria and Egypt. ${ }^{23}$ Most importantly for bin Laden, these men were committed to a single cause of waging a terrorist campaign against the enemies of Islam. These men, who had sworn allegiance to bin Laden, became the hardcore component and would serve as the foundation for Al Qaeda's future operations.

Al Qaeda's second core element is a network of co-opted groups. Many of these groups were associated with bin Laden but most had their own structures, agendas, and leadership. However, bin Laden's hardcore element acted like a state for these groups and provided sanctuary, resources, and facilities that these other groups needed yet could not attain on their own. "By late 2001 bin Laden and the men around him had access to huge resources, both symbolic and material, which they could use to project their power and influence

\footnotetext{
${ }^{22}$ Ibid., 8.

${ }^{23}$ Jason Burke, Al Qaeda: Casting a Shadow of Terror. (I.B. Tauris \& Co. Ltd., London, UK.), 2003.
} 
internationally.” ${ }^{24}$ The Al Qaeda hardcore element supported these other groups, acting as an intermediary when differences or conflicts emerged between the groups. Al Qaeda provided a connection or network for the broad movement of Islamic militancy groups. Despite having an effective hard core element and a loyal network of co-opted groups, Al Qaeda’s final core element emerged as its most important factor.

Prior to the US invasion of Afghanistan in October 2001, young Muslim men flocked to Afghanistan seeking military and terrorist training in order to devote their lives to the most extreme end of Islamic militancy. They believed in Al Qaeda, shared bin Laden's ideas and objectives, and subscribed to the Al Qaeda worldview. ${ }^{25}$ Since the US invasion of Afghanistan, the hardcore element of $\mathrm{Al}$ Qaeda has been isolated; many members within this nucleus have been either captured or killed. As the hardcore elements have been forced into isolation and seclusion, increased security and improved counter-terrorism campaigns have forced the networked groups to disperse. The networks that relied on bin Laden for safe-haven and resources were forced to look elsewhere for support. Despite international success against Al Qaeda, the efforts of Western government, local regimes, and security agencies across the world have been unable to break up this third element of Al Qaeda. "The idea of Al Qaeda, the precept, the maxim, the formula, not the base is more powerful than ever.” ${ }^{26} \mathrm{Al}$ Qaeda’s ideology, not its charismatic leader, its nucleus of hard-core component, or its network of co-opted groups has proved to be its most important element.

Al Qaeda’s ideology is based upon an “extremist Islamic fundamentalist set of beliefs that borrows many characteristics of European fascism and Marxism-Leninism.”27 Osama bin Laden follows a Sunni form of Islamic fundamentalism called Salafism, which began in the late

\footnotetext{
${ }^{24}$ Burke, Al Qaeda: The True Story, 12.

${ }^{25}$ Ibid., 14.

${ }^{26}$ Ibid., 14.

${ }^{27}$ Beyond al-Qaeda, xvii.
} 
$19^{\text {th }}$ century. Salaf is the Arab word for 'ancient ones' and refers to the companions of the Prophet Muhammad. ${ }^{28}$ "For a Salafi, Islamic authority rests only in the scripture of the Prophet (the Quran) and in the words and deeds of the Prophet as documented by his companions (the texts called Sunna, a part of the Hadith), while all the more recent interpretations are considered as suspect deviations, corrupted by non-Islamic influences, that dilute the authentic message of God.” ${ }^{29}$ Salafism portrayed Muslims as having lost their way in the modern era and espoused that Islam could only renew itself through a return to the practices of the first generations of Muslims, the Salaf.

A half century later, another group was to redirect the fundamentalist orientation of Salafism: Hassan al-Banna and Sayyid Qutb of the Egyptian Muslim Brotherhood rejected Western liberal influences and injected a more extreme understanding of Islam into Salafism. ${ }^{30}$ This new idea merged with Wahhabism, an older movement that also rejected modernism and emphasized the tenets of jihad (holy struggle) and takfir (declaring another Muslim an infidel) in 20th century Saudi Arabia. Today, Wahhabism focuses on bringing Muslims back to a strict and literal imitation of the Islam of the Prophet but discourages violence as a legitimate means to achieving this goal. Salafi-jihadism has emerged as a hybrid of Salafism and Wahhabism rejecting the traditional understandings of Islam along the lines of early Salafism, while accepting the innovations of Qutb and Wahhabism in disdaining the West and proclaiming the prominence and acceptability of jihad and takfir. Salafi-jihadism, the ideology of Al Qaeda, sees American policies as introducing foreign norms into Muslim culture and in creating a system that oppresses Muslims. The Salafi-jihad believes that all westerners and Israelis are evil and intend to exploit

\footnotetext{
${ }^{28}$ Robert Pape, Dying to Win: The Strategic Logic of Suicide Terrorism. (Random House Publishing, New York, 2005),106.

${ }^{29}$ Ibid., 106.

${ }^{30}$ Unfolding the Future of the Long War, 16-17.
} 
and control Arab lands and resources. The solution to this threat is to take up arms against the Americans, establish an Islamic caliphate, and wage war against the West and its Muslim allies.

Al Qaeda desires to create an Islamic government according to their ultra-orthodox interpretation of Hanbali Sunni Islam while isolating other Sunni and Shi'ite Muslims. The Hanbali School is the fourth orthodox school of law within Sunni Islam and it derives its decrees from the Qur'an and the Sunnah, or the way and the manners of the prophet Muhammad. ${ }^{31}$ These Sunni radicals are frustrated with the tribally based and highly corrupt autocracies that seem to ignore their own people and answer only to the infidel Westerners. They are extremely hostile towards the very concept of a nation-state, Sunni radicals share a belief that a return to a caliphate—an expansive, stateless empire based upon Sharia law and governed by a single Sunni clerical vanguard — was the ideal outcome of the necessary overthrow of the modern order across the Islamic world. ${ }^{32}$ Their ideology is internationally oriented attempting to contextualize local conflicts as part of a broader, global struggle against apostasy and the infidel.

Today’s ideologically motivated terrorists often overshadow state-sponsored terrorism. These terrorists benefit from modern communication and transportation, have global funding, possess a high degree of technical knowledgeable about modern explosives and weapons, and are much more difficult to stop than those sponsored by states. ${ }^{33}$ Lacking state sponsorship, Al Qaeda has created a series of highly effective and successful autonomous cells that can circumvent traditional US and Western means of countering them while waging a global jihad against the US and its allies. Bin Laden, serving at the top, maintains control over the large, more strategic operations yet allows the regional cells to maintain their own local autonomy. Within $\mathrm{Al}$ Qaeda’s unique structure, Shura majilis serve bin Laden as a consultant council for daily

${ }^{31}$ Hisham Ramadan. Understanding Islamic Law: From Classical to Contemporary. (Alta Mira Press, 2006), 26.

32 Sunni and Shi'a Terrorism, 24.

${ }^{33}$ Al Qaeda, 4-5. 
operational and management details. They receive information from four subordinate committees designed to focus on the specific segments of planning and operations for the Al Qaeda network. ${ }^{34}$ The four committees that support Al Qaeda are: the military, finance, religious/legal, and media committees.

Al Qaeda’s military committee is the largest and most active and is responsible for recruiting, training, procuring, and launching support and military operations. ${ }^{35}$ The military committee is directly supported and sustained by the other committees. The finance committee oversees and develops Al Qaeda’s complex system of legal and illicit companies, private donors, government sponsors, and religious charities. Combining legitimate businesses and charitable organizations allows Al Qaeda to retain a substantial capability to generate large sums of capital despite actions taken by the US and the United Nations to freeze the financial assets of the terrorist organization. ${ }^{36}$ The religious/legal committee justifies Al Qaeda's actions within the context of bin Laden's radical ideology and the theological parameters of Salafi-jihadism. In order to spread his word, bin Laden relies on a media committee to produce news and information to support the Al Qaeda organizations and their objectives.”

Al Qaeda views the current phase of the jihad as a revolutionary war, and the ideological component of the struggle is thus very important and considers political action and propaganda to be just as important at some stages as military efforts are. "The jihad must dedicate one of its wings to work with the masses, preach, provide services ... The people will not love us unless they feel that we love them, care about them, and are ready to defend them." ${ }^{37}$ Convincing the people that Al Qaeda and the revolutionary Salafists are "ready to defend them" illustrates how Al Qaeda’s second in command, Ayman Al Zawahiri sees high-profile terrorist strikes against the

\footnotetext{
${ }^{34}$ Ibid., 25.

35 Ibid., 25.

${ }^{36}$ Ibid., 25.
} 
external enemy as a means of making propaganda for the Muslim masses. He calls on his followers, at this stage of the struggle, to "launch a battle for orienting the Muslim nation" by striking at the United States and Israel. ${ }^{38}$ Fortunately for the US, the revolutionaries have failed so far to mobilize and unite the masses and pious middle classes of most Arab countries.

Over time, the cornerstone of Al Qaeda's religious and political rhetoric has remained consistent. Al Qaeda expects Muslims to view themselves as a single nation and unite to resist anti-Islamic aggression on the basis of obligatory defensive jihad. Non-Islamic government is unacceptable, and Muslims should join Al Qaeda and other sympathetic groups and movements to oppose those seeking to establish secular democratic governments or to maintain existing apostate governments. In many pre-9/11 statements, Bin Laden broadened his rhetorical outreach to appeal to non-Arab Muslims, especially those concerned with or engaged in conflicts in Chechnya, Bosnia, Kashmir, and the Philippines. Since the September $11^{\text {th }}$ attacks, bin Laden has appealed directly to many national groups on the front lines of strong counter-terrorism operations, particularly the populations of Saudi Arabia, Pakistan, Iraq, and the Palestinian territories. Al Qaeda's current strategy is to internationally provoke a cycle of violence and repression that will mobilize the Sunni masses. The American invasion of Afghanistan failed to bring about this mobilization but the invasion and occupation of Iraq, combined with US support of Israel's policies in the occupied territories, may at last be triggering the radicalization of the masses and middle classes of the Arab world that al Qaeda has hoped for. ${ }^{39}$

\footnotetext{
${ }^{37}$ Christopher Henzel. The Origins of Al Qaeda's Ideology: Implications for U.S. Strategy. Parameters, Spring, 2005.

38 Ibid.

${ }^{39}$ Christopher Henzel, 78.
} 


\section{HEZBOLLAH}

I wish to draw your attention to the threat posed by this entity which has robbed Palestine: this cancerous tumor, this vile microbe, an entity that knows no limits, that spreads out wherever Israelis are, wherever there is a remnant from the Talmud or where a Jewish rabbi once sat...Hope is rising for the fulfillment of the divine promise to eradicate this cancerous plague. Death to Israel. Death to the Israelis. ${ }^{40}$

Though too numerous to recount, these advantages, more often than not, will assist counterinsurgents in removing the cultural barriers that inhibit a free and open exchange with the locals. They will aid in removing biases, prejudices, and predispositions inherent in both the locals and the counterinsurgents.

Hezbollah, or the party of Allah, is a Lebanese Shi'ite Muslim terrorist organization established by Iran with Syrian support in 1982 during the first Lebanon war. Hezbollah emerged in the Baalbek region of Lebanon's Bekaa Valley and quickly gained acceptance throughout the Shi'ite population concentrations in south Lebanon, especially Beirut’s southern suburbs. Hezbollah is motivated by Iranian radical Shi'ite Islamic ideology inculcated into the local Shi'ite population. ${ }^{41}$ Hezbollah’s ideology mirrors the same radical Islam that was preached by Iran's Ayatollah Khomeini. Today, Hezbollah serves as a strategic tool for Iran and Syria while serving as an integral part of Lebanon's political and social fabric. ${ }^{42}$ Iran continues to shape Hezbollah's ideology, providing strong political and financial backing while building up Hezbollah’s operational capability with extensive military support and terrorist training.

Hezbollah’s ideology relies on radical Islamic doctrine that emanates from Tehran calling for the total destruction of Israel and the continued struggle against the US and their presence in the Middle East. A cornerstone of this ideology is the consistent and unyielding war against Israel. Guided by a strong ideological and practical commitment against Israel, Hezbollah feels

\footnotetext{
${ }^{40}$ Sheikh Hassan Nasrallah on al-Manar Television, 1998.

${ }^{41}$ Hezbollah Hearts and Minds, 8.

${ }^{42}$ Ibid., 8.
} 
they must use all means available in their struggle with Israel. Hezbollah continuously emphasizes an extremely hostile attitude towards Israel in order to support and legitimize their terrorist activities. Since its inception, Hezbollah has conducted a bloody struggle against Israel, adopting a murderous policy aimed at promoting its strategic goals.

Hezbollah’s initial purpose was to expel foreign troops from Lebanon. However, their strategic goals have gone far beyond merely removing the infidels from Lebanon and today focus on the annihilation of Israel. Hezbollah is consistent in expressing its steadfast opposition to any attempts towards achieving a peace settlement with Israel. Hezbollah’s leadership strongly criticizes all those who negotiate with Israel; "There is no life and no co-existence with Israel; there is only one slogan: Death to Israel.” ${ }^{43}$ Hezbollah’s ideology justifies terrorist activity against the Israeli government and its civilians. Sheik Hassan Nasrallah, Hezbollah's extremely popular charismatic leader, legitimizes attacks on civilians by designating the entire Israeli population, including women, children, and the elderly as military opponents. For Hezbollah, there are no innocents in Israel and all Israelis must be targeted. ${ }^{44}$

Despite the Israeli Defense Force’s (IDF) retreat from southern Lebanon, Hezbollah continues to wage a terrorist campaign and conduct guerilla warfare operations against Israel. Within southern Lebanon, Hezbollah has established an extensive military infrastructure, aided and supported by both Iran and Syria. "During 1996 at least three 747 cargo jets were landing in Damascus every month ferrying weapons sent by Tehran to its minions in Hezbollah.” 45 According to Israeli and American intelligence sources, the armament included long-range Katyusha rockets, Russian-made Sagger anti-tank weapons, and other sophisticated ordnance. ${ }^{46}$ When the IDF withdrew from Lebanon in 2000, Hezbollah was able to further expand its military

\footnotetext{
${ }^{43}$ Ibid., 22.

${ }^{44}$ Hezbollah, Profile of the Lebanese Terrorist Organization. 23

${ }^{45}$ Bruce Hoffman. Inside Terrorism. 265.

${ }^{46}$ Ibid., 265.
} 
infrastructure, rivaling the capacity of many sovereign states. At the start of the 2006

Israeli/Hezbollah conflict, it was estimated that Hezbollah possessed a large arsenal of explosives, small arms, mortars, cannons, and more than 20,000 rockets and Soviet-made advanced anti-tank missiles. ${ }^{47}$ Today, Hezbollah potentially has thousands of guerilla and militia fighters within southern Lebanon and enough military equipment in order to launch devastating short-notice terrorist attacks.

Syria has also been a strong supporter of Hezbollah. Syrian President Bashar al-Assad regards Hezbollah as a strategic partner in its policy towards Israel. Syria is a known supporter of terrorism and backs Hezbollah’s policy of terrorist attacks in Israel and southern Lebanon. Syria provides Hezbollah with safe-haven and freedom of operation, preventing the Lebanese government from enforcing its authority even within the borders of Lebanon. "Hezbollah provides a clandestine weapon to be wielded whenever the situation is appropriate and the benefits tangible, but one to keep sheathed when the risks of using it appear to outweigh the potential gains and the possible repercussions are likely to prove counterproductive." ${ }^{48}$ Through Hezbollah, Syria maintains its alliance with Iran, gains the means for striking indirectly at Israel and the United States, and keeps its Lebanese allies in check. State-sponsorship from Iran and Syria has transformed Hezbollah from a troublesome terrorist group into a strategic threat.

In addition to Israel, Hezbollah also bears deep hostility towards the US. Hostility towards the US is one of the main components of their ideology and has its roots in the Iranian revolutionary doctrine which defines the US as the big Satan. This ideological hostility against the US was acted out through a series of terrorist attacks in 1982. During these attacks, dozens of Americans were killed in military and civilian compounds in Lebanon and Saudi Arabia. On April $18^{\text {th }} 1983$, Hezbollah car bombed the US Embassy in Beirut killing 63 people. Six months later on October $23^{\text {rd }} 1983$, the US Marine compound and the French detachment of the

\footnotetext{
${ }^{47}$ Hezbollah as a Case Study for the Hearts and Minds. 8.
} 
Multinational Force in Beirut were car bombed killing 241 US troops and 58 French paratroopers. Hezbollah has also successfully targeted Jewish interests in South America. On March $17^{\text {th }}$, 1992 Hezbollah bombed the Israeli Embassy in Buenos Aires, Argentina killing 29 people. On July $18^{\text {th }}, 1994$ Hezbollah attacked a Jewish community building in Buenos Aries taking 86 lives and injuring several hundred. Hezbollah has also been linked to numerous hijackings and countless kidnappings throughout the Middle East, Europe, and South America.

Hezbollah’s incitement and propaganda against the United States has been greatly elevated since America declared a global war on terror. Hezbollah runs an effective antiAmerican campaign and propaganda apparatus in Lebanon, backed by Iran, which is heard throughout the Arab and Islamic world. Hezbollah uses their own al-Manar satellite television station, al-Nour radio, several publication houses, and multiple websites to spread their anti-US hate messages and propaganda. In addition to al-Manar, Arab television stations provide a public stage which enables Hassan Nasrallah to circulate his hate messages. In anticipation of the US invasion of Iraq, Nasrallah alleged that the United States' true intentions for conducting the war was the struggle against Islam, because Islam is what is keeping the US from world domination. ${ }^{49}$ Nasrallah criticizes pro-Western Arab regimes and calls on them to challenge the war waged by the United States on Islam.

In 2001, Hassan Nasrallah stated that "the culture of resistance, the culmination of humanity and human dignity is the decision to perform istishhad or to seek martyrdom in order to grant life to one's people and dignity to one’s nation and homeland.” ${ }^{50}$ He further added "to disobey all those who tell you that it is prohibited to carry out acts of istishhad because istishhad is the shortest road to Allah and is of supreme value.” ${ }^{51}$ Sheikh Naim Qassem, Hezbollah’s

\footnotetext{
${ }^{48}$ Bruce Hoffman, 267.

${ }^{49}$ Ibid., 267.

${ }^{50}$ Hezbollah: Profile of the Lebanese, 32.

${ }^{51}$ Ibid., 32.
} 
Deputy Secretary General in 2002 claimed that “all people must aspire to shahada” or martyrdom by suicide for the sake of Allah. ${ }^{52}$ However, for Hezbollah the use of this weapon should be selective but Nasrallah encourages the Palestinians to apply it daily for routine terrorist attacks.

He further claims that suicide attack is the only way to wipe out the Zionists and that these suicide acts, not the United Nations, will protect the Palestinians.

Hezbollah’s leadership believes that suicide attacks "shake the enemy from within, they plunge him into an existential crisis, and thus prepare the ground for victory.” 53 They see suicide attacks as legitimate because no one in Israel is innocent; to Hezbollah, all Israelis are occupiers and accomplices to crime and massacre. Hezbollah originated this innovative doctrine advocating the widespread use of the suicide weapon to promote strategic goals within southern Lebanon and Israel. Hezbollah applied the weapon of suicide in a series of spectacular terror attacks against Western and Israeli targets in Lebanon during the 1980s and 1990s using car bombs operated often by suicide bombers. Hezbollah encourages the Palestinians to keep up the practice of using the suicide weapon applying ideological justification to legitimize this practice against civilians, prompting the entire Arab world to use this weapon against Americans. Advocating suicide bombings exemplifies the cynical manipulation by Hezbollah of Shiite religious values, distorting them into Sunni-Islamic principles for the sake of the Palestinian struggle. Hassan Nasrallah, inspired by Ayatollah Khomeini's radical Islamic doctrine, has turned the weapon of suicide into a key element of Hezbollah’s leading asymmetric strategy of jihad to be waged against Israel. He regards it as a necessary lethal weapon in the hands of the weaker group in its struggle against the stronger and larger adversary.

In addition to significant military capabilities, Hezbollah has built an extensive civilian infrastructure throughout southern Lebanon. Hezbollah has established numerous facilities and institutions for education, health, religion, social services and propaganda. However, the primary

\footnotetext{
${ }^{52}$ Ibid., 32.
} 
focus for Hezbollah's efforts is Lebanon's Shi'ite community, the most underprivileged among the ethnic communities there. ${ }^{54}$ These civilian facilities enable Hezbollah and Iran to advance their sectarian interests politically, economically, and socially throughout southern Lebanon. Hezbollah’s civilian services and activities have established a broad power base within the Shi'ite community and enabled them to become an influential factor in Lebanon's internal politics. This aid has also earned Hezbollah the trust and support of the non-Shi'ite members of Lebanon. In stark opposition to Al Qaeda, Hezbollah articulates a universalistic view of the Muslim community that incorporates the Shiite, Sunni, and even secularists. ${ }^{55}$ This extreme holistic view allows Hezbollah to pick-and-choose the Islamic movements and associates they support such as the predominantly Sunni, Palestinian Liberation Organization (PLO). Hezbollah’s primary strategic and operational objective of removing Israeli forces from Lebanon is supported by many Lebanese.

Hezbollah has filled a political and ideological vacuum in Lebanon by providing public services, extensive relief, and charity networks and is winning the battle for hearts and minds among many Lebanese. In the battle for hearts and minds, Hezbollah uses many methods to influence, directly or indirectly, the perceptions and insights of their target audiences. They use education, indoctrination, information, propaganda and psychological warfare. The battle is waged not only to reinforce the positions of supporters but to win over neutral and hostile target audiences. The weapons used are often virtual; pictures and video shown on local and satellite television, the written word, hard-copy media, the Internet, radio broadcasts, and sermons from the local mosques. ${ }^{56}$ The damage caused by such virtual weapons and their long- and short-term influence on morale are no less than those of real bombs or bullets. These virtual weapons

\footnotetext{
53 Ibid., 24.

${ }^{54}$ Hearts and Minds, 9.

${ }^{55}$ Beyond al-Qaeda part 8.

${ }^{56}$ Hearts and Minds, 11.
} 
influence the motivation, will, and determination of both sides to continue the battle, despite the difficulties and the harm done to morale. Hezbollah’s broad network of educational, cultural, and religious institutions are intended to shape the Shi'ite mindset to their ideology. ${ }^{57}$

Hezbollah’s yearly budget is approximately $\$ 100$ million, originating primarily from Iran. ${ }^{58}$ Hezbollah is becoming more and more adept at raising its own money, taking full advantage of the internet in order to increase its annual funding, using numerous websites to collect donations. Their annual budget funds both the military-terrorist activity and its communal institution operations. Hezbollah’s communal institutions include the large number of schools, hospitals, and relief institutions they help support throughout the region.

Hezbollah successfully raises millions of dollars annually in Lebanon as well as ShiiteMuslim communities in the Ivory Coast, the tri-border region of South America, and some areas throughout Western Europe and the United States. ${ }^{59}$ Hezbollah has successfully raised money in areas with sizable Shi'ite populations of southern Lebanese origin, such as New York, Boston, Los Angeles, and Detroit. ${ }^{60}$ Many of these US cities have well organized Hezbollah charity funds that have only been slightly curtailed since 9/11. In addition to financial support, Hezbollah finances its operations through both legitimate businesses and criminal activity. Their legitimate business dealings are typically oil ventures, real estate, and small businesses investments. Hezbollah’s criminal activity mainly focuses on trafficking illegal drugs and money forgery (primarily US \$100 bills). ${ }^{61}$ Hezbollah’s party within the Lebanese Parliament easily persuades governmental officials to fund Hezbollah-sponsored projects throughout the Lebanese Shiite population centers.

\footnotetext{
${ }^{57}$ Ibid., 11.

${ }^{58}$ Ibrahim Warde, The Price of Fear. University of California Press, Los Angeles, CA. 2007. 172.

${ }^{59}$ Hezbollah: Profile of the Lebanese Shi’ite Terrorist Organization, 52.

${ }^{60}$ Ibid., 87.

${ }^{61}$ Ibid., 51-51.
} 
Much like Al Qaeda, Hezbollah’s terror campaigns and on-going battle for hearts and minds are waged on the backdrop of the communications revolution. However, Hezbollah is the only known terrorist organization in the Middle East to possess a satellite television studio, a radio station, publishing houses, and a vast Internet presence. ${ }^{62}$ The organization operates a number of powerful communications sources including al-Manar television and al-Nour radio station. These outlets provide continuous coverage of events within Lebanon, Israel, and other parts of the Middle East. Al-Nour broadcasts statements of Nasrallah and other Hezbollah leaders to a worldwide audience. Hezbollah also publishes two political and religious magazines, alIntiqad and Baqiatollah. They are used to incite and spread propaganda to a large public audience in the Arab world, especially the Palestinians. This media empire can reach the organization's various target audiences with a single, uniform propaganda strategy that permits zero internal criticism and allows very few unintended leaks. Hezbollah has become a model for other terrorist organizations, including Al Qaeda and Hamas, in the battle for hearts and minds.

${ }^{62}$ Ibid., 12. 


\section{DIVERGENCE BETWEEN AL QAEDA AND HEZBOLLAH}

The goal of modern warfare is control of the populace, and terrorism is a particularly appropriate weapon, since it aims directly at the inhabitant. In the street, at work, at home, the citizen lives continually under the threat of violent death. In the presence of this permanent danger surrounding him, he has the depressing feeling of being an isolated and defenseless target. The fact that public authority and the police are no longer capable of ensuring his security adds to his distress. He loses confidence in the state whose inherent mission is to guarantee his safety. He is more and more drawn to the side of the terrorists, who alone are able to protect him. ${ }^{63}$

Despite many similarities, significant divergence exists between Hezbollah and Al

Qaeda. The overarching difference between Hezbollah and Al Qaeda is state-sponsorship.

“Terrorist attacks sponsored by states have declined in recent years but remain a serious threat.

With state sponsorship a terrorist group can receive safe-haven, money, weapons, training, logistic support, and use of diplomatic facilities. "64 Enhanced resources available to sponsored terrorists enable their terror attacks to be more effective and more lethal. Many of the most violent terrorist attacks on record were made possible by state sponsorship. State-sponsored attacks during the 1980s were eight times more lethal than attacks executed by terrorist groups without state-sponsorship including two attacks in Beirut against US interests, multiple attacks in Pakistan and Argentina, as well as the Pan American Flight 103 over Lockerbie, Scotland. ${ }^{65}$ Iranian and Syrian state-sponsorship provides tremendous financial, material, and ideological support to Hezbollah. State-sponsorship allows Hezbollah to use Iran’s overseas embassies, consulates, and cultural centers to facilitate terrorism. Hezbollah operatives are able to work under diplomatic cover to recruit agents, plot activities, and facilitate terrorism. Ahmed AlMughassil's (also known as Abu Omran) indictment and conviction for the 1996 Khobar Towers

${ }^{63}$ Roger Trinquier, Modern Warfare: A French View of Counterinsurgency. (Pall Mall Press, London. 1964), 16.

${ }^{64}$ Department of State Publication 10610 Office of the Secretary of State Office of the Coordinator for Counterterrorism. April, 1999.

${ }^{65}$ Bruce Hoffman, 261-262. 
bombing confirmed the role of both Hezbollah and the Iranian Embassy within Syria in the planning, surveillance, and execution of the attack that killed nineteen Americans and injured 372 others. ${ }^{66}$ State sponsorship of Hezbollah allows Iran to conduct covert operations against Israel and US forces in the Middle East without implication or a potential international military response.

Al Qaeda shares no parallel construct of state sponsorship. Al Qaeda’s historical pattern of Sunni radical terrorism "has most often promulgated along a web, hubbed around a radical mosque” forced to focus recruiting, organization, and planning activities in and around radical mosques, extremist-learning centers, and fundamental madrassas. ${ }^{67}$ Al Qaeda’s unique structure of linked global cells provides tremendous flexibility. These global cells remain adaptive; they can generate their own capital and plan their own operations. Despite the lack of statesponsorship and tremendous pressure from the US and the UN, Al Qaeda is still very effective and remains quite influential in the world's political spectrum.

In addition to state sponsorship, there are five other areas where Hezbollah and Al Qaeda show major divergence. First, Al Qaeda and Hezbollah differ in their overall approach, motivation, and main objectives for using terror. Second, Al Qaeda relies more heavily on their coreligionist expatriate community to facilitate their activities than does Hezbollah. Third, despite similar techniques and tactics, Al Qaeda typically kidnaps to kill; Hezbollah’s propensity is to kidnap innocents in order to barter with them. Fourth, Hezbollah exhibits a much higher incidence of targeted assassinations for specific political gains versus the casualty killings of $\mathrm{Al}$ Qaeda’s terrorism. Finally, Al Qaeda’s information operations and propaganda campaigns feature doctrine and resources geared to taking immediate credit to amplify their terrorist events. In

\footnotetext{
${ }^{66}$ USA vs. AHMED AL-MUGHASSIL aka “Abu Omran,” Indictment, June 2001.

${ }^{67}$ Sunni and Shi'a terrorism. 43.
} 
regards to strategic communications and propaganda, Hezbollah takes a more profound, yet lowkey approach towards their information operations campaigns. ${ }^{68}$

Divergent philosophies between Sunni radicalism and Shi'a extremism manifest themselves in Al Qaeda's wave-like terrorist attacks while Hezbollah's terrorism appears as campaigns in support of Iranian national objectives or Hezbollah's own organizational objectives. ${ }^{69}$ Al Qaeda pursues broad ideological goals of Salafi-jihadism in hopes of realizing a Sunni Islamic caliphate. Al Qaeda attempts to strike decisively and dramatically against US interests and vulnerable Arab and Muslim state regimes to drive Westerners from the holy Muslim lands. Al Qaeda’s 12 October 2000 attack against the USS Cole while in port at Aden, Yemen killed 17 US sailors and injured dozens more. Al Qaeda hoped attacks like this would cause the US to withdraw from the Middle East. Al Qaeda also pressures vulnerable Islamic state regimes in hopes of establishing safe haven. Safe havens, like what they had in Afghanistan under the Taliban regime would enable Al Qaeda to pose a greater threat against western targets and apostate regimes throughout the Muslim world. Hezbollah’s terror campaigns do not display the same level of ideological motivation as Al Qaeda.

Hezbollah’s terror emerges from either Iranian or Syrian objectives or Hezbollah’s own political objectives or when Iran's regime has felt threatened. Hezbollah’s terror campaigns typically run a course that effectively ends when the policy objective is realized. Hezbollah’s suicide attacks against the US Embassy and US Marine Barracks in Beirut in 1983 were in response to the threat that Tehran felt from the US presence in Lebanon. Past terror campaigns have had succinct goals and have helped secure the Shi'a Islamic movement. They have also safeguarded the Shi'a state of Iran and neutralized both regional and global threats to their operations in southern Lebanon. Hezbollah is motivated by distinct policy objectives that feature discrete start and stop points linked to achieving purposeful objectives. To accomplish these

\footnotetext{
${ }^{68}$ Sunni and Shi’a Terrorism, 6.
} 
objectives, Hezbollah uses an array of tactics including suicide bombings, kidnappings, and targeted assassinations, often from the safety and concealment of Iranian protectorates. Al Qaeda employs similar tactics without the protection of a nation-state instead relying on the protection offered by an empathetic Sunni Muslim community.

Hezbollah operatives tend to operate among co-religionists who are oblivious to their activity, while Al Qaeda and Sunni extremists work within a Muslim community that claims to oppose politically motivated terrorism, but remains empathetic with terrorist grievances and their proclaimed anti-oligarchy, anti-western outlook. ${ }^{70}$ Ahmed Al-Mughassil and his fellow 1996 Khobar Towers attack conspirators were Shi'a Muslims who shared Tehran's belief that American military presence in the Kingdom was a threat to Islam in general and Iran specifically. They were from the Shi'a diasporas in Saudi Arabia, but their terrorist activities were impossible to conduct without the external sponsorship from Iran and Hezbollah. Conversely, Abu Moath and his colleagues in the 1998 bombing of the U.S. Embassy in Kenya were not Kenyan, and were inspired, facilitated, and supported by Al Qaeda and Salafi-Jihadist organizations in Sudan and elsewhere across the Arab Muslim world. ${ }^{71}$

Al Qaeda harbors xenophobic tendencies making them highly intolerant of moderate Muslims and deeply suspicious of both liberal Muslims and non-Muslims alike. Al Qaeda relies on empathy from across the Sunni Muslim community, a community that at least in part, feels oppressed by the western world and corrupt Islamic oligarchs for more than a century. This empathy allows Al Qaeda freedom of action to conduct terror against apostate governments and western infidel targets. Hezbollah terrorists operate among Shi’a Muslims who remain generally oblivious to the terrorists' goals and activities and often conduct operations in areas where the Shi’a Muslim Diaspora is very small, such as France in the 1980s and Argentina in the 1990s.

\footnotetext{
${ }^{69}$ Ibid., 41.

${ }^{70}$ Sunni and Shi'a, 45-46.

${ }^{71}$ Ibid., 46.
} 
Hezbollah articulates a universalistic view of the Muslim community that incorporates the Shiite, Sunni, and even secularists. ${ }^{72}$ As previously mentioned, this universalistic view allows Hezbollah to pick the Islamic movements and associates that they want to support.

Al Qaeda’s intense xenophobia inhibits the use of third parties and surrogates in the planning and execution phases of their terrorist operations; Shi'a creativity in support of terror is far less constrained. “Hezbollah’s relationship with Iran and Syria has made operations much more diffuse and entrepreneurial as their operatives have shown a willingness to subcontract or outsource for terrorist operations.” ${ }^{73}$ Hezbollah is not afraid to work with other non-Muslim terror agents. Effective third-party use can greatly enhance global presence and a terrorist group’s ability to kidnap and assassinate their victims.

The likely outcome in most Al Qaeda kidnappings is death. Hezbollah inspired kidnappings have a more consistent track record of abducting to barter and negotiate. Hostage negotiations are extremely important to Hezbollah in attaining their political objectives. "In the course of nearly forty kidnappings during the 1980s, Hezbollah and Iran parlayed live, extended captivity hostages, into direct and indirect negotiating pressures that helped secure a myriad of favorable outcomes. From ransom money to weapons transfers, to prisoner exchanges and more, Shi'a extremists learned the value of taking prominent westerners hostage and then bartering with them in the pursuit of political aims.”,74

In contrast, Al Qaeda kidnappings conducted by Salafi-jihadi terrorists, typically abduct to kill. Al Qaeda often uses multiple media outlets to quickly claim credit for abduction but rarely address bargaining arrangements. For Al Qaeda, the abduction is often the terror event and AlQaeda sees tremendous propaganda value in killing their victims. "In more than 50 percent of the 115 cases identified, Al Qaeda and other jihadi-inspired terrorists never declared hostage-release

\footnotetext{
72 Beyond al-Qaeda: The Outer Rings of the Terrorist Universe. RAND Corporation. 2006. 8.

73 Sunni and Shi'a, 47.

${ }^{74}$ Ibid., 53.
} 
criteria. In over 60 percent of these abduction cases, victim's bodies, or the very act of killing the victim, were recorded and rapidly released to mass media outlets and the internet.” ${ }^{75}$ US counterterrorism strategies must respond differently to these divergent outcomes. The US must deny Hezbollah from attaining its political goals after a kidnapping and Al Qaeda must be denied a strategic communications victory.

The fates of two American hostages Terry Anderson and Paul Johnson are typical of what can be expected when abducted by either Hezbollah or Al Qaeda. Terry Anderson was the Associated Press Bureau Chief in Beirut when he was abducted by Lebanese Shi'a extremists in 1985. Anderson's ordeal was a typical Hezbollah terrorism kidnapping; he was kept alive and used as a human bargaining chip and put America at a point of disadvantage. “Terry Anderson (who was released in 1991) was among the better than 90 percent of non-Israeli hostages taken by Hezbollah who survived captivity in Lebanon during the 1980s and early 1990s.”,76

Lockheed Martin Engineer Paul Johnson’s fate under Al Qaeda was markedly different. He was kidnapped and beheaded by Al-Qaeda in Saudi Arabia in June 2004. "Disturbing visuals of the beheading's aftermath were posted rapidly to the internet for worldwide circulation. Quickly claiming credit but never setting demands for Johnson's safe release, Al Qaeda heralded this event as a great victory for their cause of intimidating infidels and ending the illegitimate presence of western occupation in the Land of the Two Holy Mosques." 77 Paul Johnson’s unfortunate fate remains typical of those targeted for abduction by Al Qaeda.

Hezbollah and Al Qaeda have significantly different approaches to targeted killings. Hezbollah has shown a much higher incidence of targeted assassination for specific political purposes. Salafi-jihadism inspired Al Qaeda terrorist attacks typically result in high casualty counts and considerable collateral damage. Hezbollah attacks show "a propensity toward

\footnotetext{
${ }^{75}$ Ibid., 54.

${ }^{76}$ Sunni and Shi’a, 52.

${ }^{77}$ Ibid.,52.
} 
individual, targeted killings of specific people with a calibrated eye toward minimizing collateral damage to surrounding individuals and property.”78 The specific targets for Sunni terrorist killings are more ambiguous. The line between their targeted killings and a more generic attack against a hated group or location often is blurred. In the case of an attack against a US embassy, Hezbollah is more likely to assassinate the ambassador or other governmental officials where $\mathrm{Al}$ Qaeda is more likely to bomb the entire embassy killing dozens of people. Since the bombings of the two US embassies in Kenya and Tanzania in 1998 and the 9/11 attacks in 2001, the US has begun to safeguard significant overseas political, cultural, and executive buildings thwarting potential Al Qaeda attacks. Hezbollah would most likely target US diplomats, government officials, military leaders and prominent businessmen and educators, forcing the US to reprioritize its safeguarding efforts and counterterrorism policies throughout the world.

Al Qaeda and Hezbollah have fundamental differences in their approach to publicity and propaganda of terror events. Al Qaeda's approach to information management tends to feature doctrine and resources geared to take immediate credit and to widely amplify a terrorist event, treating publicity as an independent variable to be manipulated and enhanced. ${ }^{79}$ Hezbollah has shown a propensity toward low-key publicity regarding specific terrorist incidents and a reliance on normal press coverage to broadcast their attacks. They seem to prefer plausible deniability in their operations in order to avoid retribution or global condemnation. Al Qaeda is identifiable with immediate image transmission and attack glorification using advanced and sophisticated media outlets. For Al Qaeda, recording and documenting their terror attacks is essential. They use additional operatives to record the attacks for rapid transmittal, exploitation, and propaganda. Al Qaeda has developed its own media production capability. Al Shahab is responsible for Al Qaeda’s media production and al Fajr handles Al Qaeda’s media distribution, promulgating

\footnotetext{
${ }^{78}$ Ibid., 55.

${ }^{79}$ Ibid., 57.
} 
images, and interpreting its terror attacks. This network takes advantage of emerging

technologies, including satellite television, cellular phones and the internet. Following the 1998

U.S. Embassy bombings in Kenya and Tanzania, Al Qaeda was able to globally broadcast information on the attacks, disseminate images of death and destruction, and claim credit for the attacks.

Despite their propensity for low-key publicity, Hezbollah has its own media empire. Hezbollah uses its media sources to promote the Palestinian struggle, provoke the escalation of terrorism, exert pressure on the moderate/Pro-western Arab regimes, and to enhance the status and impact of Hezbollah. ${ }^{80}$ Al-Manar and al-Nour target Israel and western nations with psychological warfare messages to demoralize Israel. Hezbollah prefers to let their terrorism speak for itself and rarely champions their own work.

The divergence between Al Qaeda and Hezbollah terror is meaningful. US counterterrorism efforts will be challenged without Al Qaeda-like quick claims of responsibility. Al Qaeda's obsession with the immediate image and rapid dissemination of their attacks allows counterintelligence and law enforcement a pattern for use in safeguarding prominent, highly visible potential terror targets. Future Hezbollah terror targets will be much harder to determine and deter, and when the targets have been attacked, the operatives will be much harder to track down and capture.

${ }^{80}$ Hala Jaber. Hezbollah: Born with a Vengeance. Columbia University Press. New York. 1997. $42-43$. 


\section{COUNTERING AL QAEDA, HEZBOLLAH, AND THEIR IDEOLOGIES}

Jihadis want a totalitarian system of government in which no one is allowed to think for themselves. Not even the Saudi government is strict enough. Anyone who does not share their understanding of Islam will be declared an apostate and executed. If you want to know what a Jihadi state will look like, contemplate the Taliban-the only state in recent memory that Jihadis consider to have been legitimately Islamic. The Jihadi message is so weak and unappealing that they have to use violence to persuade people. They claim to be saving Islam, but they are giving it a bad reputation. They are hurting their own people and national resources. ${ }^{81}$

"While all warfare is an expression of politics, none is more pervasively so than irregular conflict. The irregular side, most probably employing a mixture of guerilla tactics and terrorism, will seek favorable political effect from several courses of action.” ${ }^{82}$ Combating terrorism has become a global effort. "Counterterrorism is a protracted attritional struggle of political wills. It is waged preeminently by the police and other security services, with the military typically in reserve. The most important weapon in the arsenal of the counter-terrorist is information.” ${ }^{83}$ The war of ideas is crucial for today’s terrorist and insurgent. Two of the major terrorist organizations that pose the greatest potential threat to the US are Al Qaeda and Hezbollah; both are motivated by two very powerful yet distinct ideologies.

Al Qaeda and Hezbollah may not share the same ideology, but ideology is a key component of why these groups undertake violent action. An ideology is a framework of ideas that describes a view of reality and a set of social and political actions that should be undertaken to change and improve the situation of a particular group. ${ }^{84}$ To succeed, the insurgent or terrorist must win the war of ideas; the counter-terrorism forces cannot allow this to happen. Ideologies are difficult to combat using military forces, because ideas are extremely difficult to contain or

${ }^{81}$ William McCants, PhD Militant Ideology Atlas Executive Report, Combating Terrorism Center, West Point, NY, November 2006, 7.

${ }^{82}$ Gray, 254.

${ }^{83}$ Ibid., 258. 
destroy. Both Al Qaeda and Hezbollah function and thrive in the absence or weakness of governments operating in ungoverned territories, taking advantage of weak states to smuggle weapons, money, and other resources. Unable to compete in a direct confrontation with regular, host nation forces, these groups use asymmetric tactics such as terrorism to engage their enemies and further their ideologies.

Defeating insurgencies and terrorism has always been challenging for Western militaries. Defeating Al Qaeda and Hezbollah requires a global, strategic response. Al Qaeda and Hezbollah present tremendous challenges for COIN and counter-terrorist forces. Culturally, their organizations are both very difficult to penetrate for non-Muslim or non-Arab counter-terrorist or counter-intelligence forces. Al Qaeda and Hezbollah are both experienced in irregular warfare operations and tactics. Al Qaeda continues to hone these skills in operations within Iraq, Afghanistan, and Pakistan as well as many other regions throughout the world. Hezbollah's successes against Israel have made them role models to other Islamic terrorist groups in the region. Al Qaeda’s perceived success against the US, especially the 9/11attacks, has gained them global iconic status. Al Qaeda does not intend to overthrow apostate rulers and their regimes. They want to discredit them, causing chaos, and disorder with their states.

Both groups will exploit failed or failing states and ungoverned spaces to create small pockets of Islamic resistance, to serve as bases for training and launching attacks against US and Western interests. However, Hezbollah is more inclined to focus on states with Iranian embassies or consulates in order to conduct its operations. To deny Hezbollah safe havens and training areas, US intelligence efforts must focus on vulnerable embassies and Shi'a diasporas within weak and failing states that appear to be open to Shi’a inspired activities. Al Qaeda will likely target the small enclaves within ungoverned spaces. In the long-term, Al Qaeda hopes these small enclaves will grow and mature into the global caliphate, eventually stretching from the Atlantic to

\footnotetext{
${ }^{84}$ Unfolding the Future of the Long War, 125.
} 
the Pacific Oceans. To counter this, the US must rely on local surrogates to prevent the establishment of these enclaves, deny Al Qaeda tactical successes, and strategic propaganda victories. It is crucial for the US to avoid additional large-scale military engagements. US forces should operate clandestinely or through proxies, relying more on local regimes, tribes, or ethnic minorities. Increased US presence may actually reduce security and increase instability if the support of local regimes is lost and a large force presence alienates the local population. If US forces are kept to a minimum and positive efforts are seen as the result of local host nation forces, Al Qaeda will have nothing to rally popular support against without a US or western face to blame. Retaliation in the form of terror attacks, kidnappings, and assassinations by Al Qaeda will be counterproductive especially if they target their own Muslim people.

Much of Al Qaeda's success and ability to survive despite the tremendous global effort to counter them is attributable to their autonomous cells and flat organizational structure, which advocate decentralized execution. Urban warehouse training centers and extensive use of the internet have replaced traditional training camps for preparing new recruits. Al Qaeda’s movement has metastasized into a self-sustaining movement in which their terror attacks are more important as a means for recruitment and inspiration than as a means to a political end. One of the major challenges facing the US and its Middle Eastern allies is the Muslim youth. Circumstances within the Middle East have left many young Muslims feeling alienated. This alienation has fueled recruitment efforts for Al Qaeda and other terror groups.

Salafi-jihadist and Al Qaeda religious leaders play a critical role in attracting disavowed Muslim youth to their movement. The religious leaders provide justification for violence, and determine strategic direction. However, non-jihadi and anti-Al Qaeda religious leaders can siphon off support from the movement and challenge its legitimacy. ${ }^{85}$ The US should carefully support these anti-Al Qaeda Muslim religious leaders and their movements in order to have any hope of

\footnotetext{
${ }^{85}$ Jarret M. Brachman and William F. McCants. Stealing Al-Qa'ida's Playbook. (Combating Terrorism Center, Westpoint NY, 2006), 21.
} 
competing with Al Qaeda and the jihadi movement. Support for Al Qaeda can only be "contained and reduced by a focused, aggressive, and compelling battle of ideas led by respected clerics and intellectuals who could draw on Islamic theology and sacred sources to make a compelling case that militant ideas and behavior, especially terrorist attacks against innocent civilians, are both un-Islamic and anti-Islamic.”

Sunni Islam's most active reformers over the past century have been its outsiders, the Salafists. It is the insiders of Sunni Islam who are America's natural allies. Many Western advocates of reformation want to see the existing secular, modernized classes in Muslim countries lead the reformation. But these politically weak classes are small elites viewed with suspicion by many. Any US effort to strengthen these elites must be a project for several decades, to be carried out quietly and with the greatest caution. The US could also pressure Middle Eastern governments to allow greater political participation and visibility for groups that oppose $\mathrm{Al}$ Qaeda and Salafi-jihadis. It is paramount for US and Western forces to put a Muslim face on this approach.

Propaganda is crucial to the terrorist and the counter-terrorist. Positive public opinion is necessary for Al Qaeda and Hezbollah to attract new recruits. Conversely, these terrorist movements decline in popularity when perceived to be attacking and killing fellow Muslims, causing public disorder, damaging critical national industries, or engaging in sectarianism. The US must fund media campaigns that focus on turning Muslim public opinion against Al Qaeda and Hezbollah but in a low key and indirect manner. Once again, the US must put an Arab or Muslim face on their efforts. Furthermore, the US must recast its ineffectual public diplomacy efforts by using surrogates and friends to avoid unwanted perceptions. Both Hezbollah and Al Qaeda possess highly experienced propaganda empires that can negate positive US efforts, generate ill will, and discredit US and ally efforts. 
Counter-terrorism, counter-intelligence, and force protection efforts in the Middle East have primarily focused on Sunni and Salafi-Jihadist inspired terror organizations like Al Qaeda. At a local level, it would seem that US efforts against Al Qaeda have severely disrupted their organization. Despite these successes, Al Qaeda has shown a remarkable ability to adapt and maintain the integrity of their terrorist training through the proliferation of a virtual, internet based jihad, and the diffusion of urban training centers within private homes and warehouse type spaces worldwide. However, Al Qaeda is not the only threat facing the US.

Hezbollah’s Iranian inspired terror remains a severe threat. Unlike Al Qaeda’s Salafijihadist ideology, Hezbollah is not directly tied to Shi'a theology or doctrine. As previously stated, Hezbollah is motivated by distinct policy objectives with discrete start and stop points linked to achieving decisive political objectives. Hezbollah will use an array of techniques from suicide bombings to kidnapping to targeted assassinations to achieve these objectives. In addition, because of the value of state-sponsorship to Hezbollah, US and western leaders should anticipate a possible intense terror campaign if and when Hezbollah or Tehran feels threatened by western policies or actions within the Middle East. US counter-terrorism policies must adapt and change to counter this unique, emerging threat. Hezbollah may seem to have been dormant, with the exception of Lebanon, in many parts of the world. Nevertheless, the US cannot rely on the current status quo, especially if the US or Israel were to instigate Iran. The US should anticipate Hezbollah to respond with terror in response to an Israeli or US military strike against Iran.

The US has naturally focused on Al Qaeda and Salafi-Jihadist inspired terrorism since 9/11 but increased attention on Hezbollah is critical for the US to protect its forces and interests overseas. As relations with Iran become more and more contested in regards to their nuclear ambitions or their role in Iraq, the US must think seriously about the ramifications of military conflict with Iran. One of Hezbollah's primary goals is to insure the survival of the Iranian regime. Hezbollah would most likely begin a new wave terrorism attacks against the US and their 
interests in response to a US or Israeli strike against Iran. Hezbollah could launch attacks from Iranian embassies and consulates throughout the globe, striking at vulnerable US interests worldwide. American policymakers must consider these vulnerabilities before taking action against Iran.

Even though Hezbollah has not directly attacked US or other Western targets in over a decade, Hezbollah has had plenty of practice and training against US or US-backed adversaries with persistent involvement in two combat zones. Hezbollah has been actively fighting against Israel as well as indirectly fighting American, coalition, and Iraqi targets in Iraq. US military forces have reported seeing Hezbollah recruitment billboards, paper flyers, and other forms of propaganda while on patrol in Shi'a dominated portions of Iraq. In addition to focusing on Hezbollah and Iranian backed terror within Iraq and Lebanon, the US must focus on susceptible areas around the globe where Hezbollah might be able to gain a foothold in order to combat the US.

“Western intelligence and enforcement agencies need to open a wider aperture to prepare for any new, concerted Shi'a terror campaign. Subcontracted bombings, kidnappings, assassinations and other forms of terror will emanate from Shi’a operatives, but be conducted among a wide range of people.” ${ }^{86}$ Increased intelligence and counterintelligence capabilities should be directed at states with weak governance; corrupt and inefficient law enforcement and legal systems; and porous borders. However, to thwart Hezbollah, counterintelligence efforts must focus on states where Iranian embassies are located. These conditions enabled Hezbollah and Iranian Republican Guard operatives to thrive in southern Lebanon in the early 1980s allowing them to successfully target US interests in Beirut. Future Hezbollah strongholds might

\footnotetext{
${ }^{86}$ Sunni and Shi’a Diffrences, 51.
} 
include the Caucasus and Central and Southwest Asia states where local terrorist groups could be used as part of a terror campaign against Americans. ${ }^{87}$

In order for US and Western counter-terrorism efforts to be successful, they must continue to focus on countering Al Qaeda and Hezbollah's ideologies. Through moderate Muslim religious leaders, efforts must focus on the need to accentuate ideological alternatives to the extremist ideologies, while at the same time undercutting the integrity of these extreme ideas. ${ }^{88}$ Efforts should engage liberal Muslims which comprise the majority of the population, in hopes of delegitimizing the terrorist's extreme beliefs. The US must assist Middle Eastern governments to prevent abuses, corruption, and bad policy that enflame extreme ideologies and legitimizes terrorism. Governments must address the typical grievances, like discrimination, unemployment, and persecution that feed these extreme ideologies and benefit the terrorist organizations. ${ }^{89}$

Intelligence and information must be the focus of the counter-terrorist efforts to counter radical ideology. In order for the US, Western governments, and Middle Eastern states to be successful, they must cooperate and consolidate their efforts. Governments must be willing to cooperate with progressive Muslim leaders, intellectuals, university scholars, non-governmental organizations, local leaders, and even rehabilitated terrorists. ${ }^{90}$ Efforts against Al Qaeda and Hezbollah can undermine their ideological basis and decouple them from local and international support and reduce the incidence of terrorism world-wide. Al Qaeda and Hezbollah have proven to be very adaptable and flexible; they have survived despite massive global efforts to destroy them. Counter-terrorist efforts must also remain flexible if they hope to defeat Al Qaeda and Hezbollah and their extreme ideologies.

${ }^{87}$ Ibid., 61.

${ }^{88}$ Anne Aldis and Graene P. Herd. The Ideological War on Terror. (Routledge Publishing, London, UK, 2007), 247.

\footnotetext{
${ }^{89}$ Ibid., 248.

${ }^{90}$ Ibid., 249.
} 


\section{CONCLUSION}

It is a persistently methodical approach and steady pressure which will gradually wear the insurgent down. The government must not allow itself to be diverted either by countermoves on the part of the insurgent or by the critics on its own side who will be seeking a simpler and quicker solution. There are no short-cuts and no gimmicks. ${ }^{91}$

"The war on terror at its most fundamental level goes to the war of ideas." ${ }^{92}$ Ideology is a powerful message that motivates and propels ordinary human beings into action. It frames organizational structure, both leadership and member's motivation, their recruitment and support, and shapes the group's strategies and tactics. Ideology, not poverty or illiteracy, is the key driver of politically motivated violence. In the post-9/11 environment, the centrality of ideology in terrorism has become increasingly evident.

Al Qaeda and Hezbollah present tremendous irregular warfare challenges. They exist locally and globally and do not subscribe to international laws of war or conduct. They are waging long-term, protracted warfare against the enemies of Islam, namely Israel and the US. They have shown a remarkable ability to regenerate their numbers, educating future generations of militants to carry on their struggle. Al Qaeda will continue to engage the United States in order to rally locals behind their movement, drain the US of its resources, and put pressure on the apostate pro-West regimes allied with the US.

Understanding the significant divergence between Hezbollah and Al Qaeda will aid the US and other Western nations engaged in global counter-terrorism efforts. The most obvious difference between Hezbollah and Al Qaeda is state-sponsorship. Sponsorship from Iran and Syria provides Hezbollah with financial support, training, and weapons. Hezbollah’s potential to strike US forces and interests from the protection of Iranian embassies and consulates worldwide

${ }^{91}$ Sir Robert Thompson. Defeating Communist Insurgency: The Lessons of Malaya and Vietnam. 1966.

${ }^{92}$ RAND Corporation, Beyond Al Qaeda, (RAND Corporation Publication, Santa Monica, CA, 2006), xxiv. 
poses a significant problem for US counter-terrorism forces. State sponsorship of Hezbollah also allows Iran and Syria to conduct covert operations against Israel and US forces and interests without implication or international response.

In addition to state sponsorship, there are several other areas of divergence between Hezbollah and Al Qaeda. Hezbollah’s ideology is motivated by political objectives, objectives oriented towards stopping Israel and the US and spreading the resistance. Hezbollah's terrorism is often Iranian focused in order to insure regime survival. Al Qaeda’s theologically oriented Salafijihadism ideology espouses taking up arms against the Americans, establishing an Islamic caliphate, and waging war against the West and its Muslim allies. Al Qaeda uses Sunni mosques and seditious Salafi-jihadist network websites to recruit and train its operatives. Al Qaeda relies heavily on the sympathetic coreligionist community to facilitate their activities. Hezbollah does not rely on Shi'a protection; it centers its efforts on Iranian embassies, consulates, and its own social service centers. Al Qaeda typically kidnaps to kill, hoping to gain an immediate propaganda victory; Hezbollah's propensity is to kidnap innocents in order to barter with them in hopes of gaining future advantage. Hezbollah exhibits a much higher incidence of targeted assassinations for specific political gains versus the high-casualty killings of Al Qaeda’s terrorism. Finally, Al Qaeda’s information operations and propaganda campaigns feature doctrine and resources geared to taking immediate credit to amplify their terrorist events. Hezbollah takes a more profound, yet low-key approach towards strategic communications and propaganda in waging their information operations campaigns.

To counter terrorist ideology and to provide an alternative ideology, it is necessary to know its key ideologues, organizational structures, the evolving ideology, and its community. Al Qaeda’s ideology simply seeks to move, incite, and mobilize the Muslim nation into global revolution against the West and Middle Eastern apostate regimes. Hezbollah’s Iranian backed ideology calls for the consistent and relentless struggle against Israel until its annihilation and 
intense hostility towards the US and its efforts to force its influence out of the Middle East. ${ }^{93}$ This paper has hopefully furthered the understanding of disparate insurgencies through a comparative analysis of Al Qaeda and Hezbollah. It has also proven that understanding the divergence between Hezbollah and Al Qaeda is crucial. Understanding this divergence will allow for differing opportunities and a more nuanced US counter-terrorism approach when combating an international non-state actor like Al Qaeda versus a state sponsor of terrorism like Hezbollah.

${ }^{93}$ Hezbollah. Intelligence and Terrorism Information Center at the Center for Special Studies, 2003. 8. 


\section{BIBLIOGRAPHY}

Aldis, Anne and Herd, Graeme P. The Ideological War on Terror: Worldwide strategies for counter-terrorism. London: Routledge Publishing, 2007.

Alexander, Yonah. Counterterrorism Strategies: Successes and Failures of Six Nations. Dulles Virginia: Potomac Books, Inc., 2006.

Brachman, Jarret M. and William F. MCants. Stealing Al-Qa'ida's Playbook. Westpoint NY: Combating Terrorism Center, February 2006.

Burke, Jason. Al Qaeda: The True Story of Radical Islam. NY: I.B. Tauris \& Co., 2006.

Chandler, Michael. Countering Terrorism. London: Reaktion Books, 2007.

Celeski,Joseph D. Operationalizing COIN. Joint Special Operations University. Sep, 2005.

Diaz, Tom and Newman, Barbara. Lightning Out of Lebanon: Hezbollah Terrorists on American Soil. New York: Ballantine Books, 2005.

Erlich, Reuven and Kahati, Yoram. Hezbollah as a Case Study for the Hearts and Minds. Intelligence and Terrorism Information Center at the Israel Intelligence Heritage \& Commemoration Center. June, 2007.

Galula, David. Counterinsurgency Warfare: Theory and Practice. Westport, CT: Greenwood Publishing Group, 1964.

Ganor, Boaz. The Counter-Terrorism Puzzle: A Guide for Decision Makers. London: Transaction Publishers, 2005.

Gray, Colin S. War, Peace and International Relations: An Introduction to Strategic History. NY: Routledge Publishing, 2007.

Headquarters, Department of the Army. FM 3-24 Counterinsurgency. Washington, D.C.: Marine Corps Warfighting Publication, 2006.

Henzel, Christopher. The Origins of Al Qaeda's Ideology: Implications for U.S. Strategy Parameters.

Hoffman, Bruce. Inside Terrorism. NY: Columbia University Press, 2006.

Intelligence and Terrorism Information Center at the Center for Special Studies. Hezbollah, Profile of the Lebanese Terrorist Organization. June, 2003.

Jaber, Hala. Hezbollah: Born with a Vengeance. NY: Columbia University Press, 1997.

Kalic, Sean N. Combating a Modern Hydra: Al Qaeda and the Global War on Terrorism. Ft Leavenworth, KS: Combat Studies Institute Press, 2005.

Lynch, Thomas F. Sunni and Shi 'a Terrorism Differences that Matter. Combating Terrorism Center at West Point. December, 2008.

Mahler, Gregory S. Comparative Politics: An Institutional and Cross-National Approach. NJ: Prentice Hall,1995.

McCants,William PhD. Militant Ideology Atlas Executive Report. West Point, NY: Combating Terrorism Center, 2006.

Nasrallah, Sayyed Hassan. Voice of Hezbollah: The Statements of Sayyed Hassan Nasrallah. London: Verso Publishing, 2007. 
Norton, Augustus Richard. Hezbollah: A Short History. Princeton: Princeton University Press, 2007.

Office of the Secretary of State Office of the Coordinator for Counterterrorism. Department of State Publication 10610. April, 1999.

O’Neill, Bard E. Insurgency and Terrrorism: From Revolution to Apocalypse.Washington, D.C.: Potomac Books, Inc., 2005.

O’Sullivan, Meghan L. Shrewd Sanctions: Statecraft and State Sponsors of Terrorism. Washington, D.C.: Brookings Institution Press, 2003.

Pape, Robert A. Dying to Win: The Strategic Logic of Suicide Terrorism. New York: Random House Publishing, 2005.

Pernin, Christopher, Brian Nichiporuk, Dale Stahl, Justin Beck, and Ricky Radaelli-Sanchez. Unfolding the Future of the Long War: Motivations, Prospects, and Implications for the U.S. Army. Santa Monica, CA: RAND Corporation, 2008.

Pillar, Paul R. Terrorism and U.S. Foreign Policy. Washington, D.C.: Brookings Institution Press, 2001.

Rabasa, Angel, Peter Chalk, Kim Cragin, Sara A. Daly, Heather S. Gregg, Theodore W. Karasik, Kevin A. O’Brien and William Rosenau. Beyond al-Qaeda, Part 1: The Global Jihadist Movement. Santa Monica, CA: Rand Corporation, 2006.

Rabasa, Angel, Peter Chalk, Kim Cragin, Sara A. Daly, Heather S. Gregg, Theodore W. Karasik, Kevin A. O’Brien and William Rosenau. Beyond al-Qaeda, Part 2: The Outer Rings of the Terrorist Universe. Santa Monica, CA: RAND Corporation, 2006.

Ramadan, Hisham. Understanding Islamic Law: From Classical to Contemporary. Alta Mira Press, 2006.

Stout, Mark E., Jessica M. Huckabey, John R. Schindler, with Jim Lacey. The Terrorist Perspectives Project: Strategic and Operational Views of Al Qaida and Associated Movements. Annapolis: Naval Institute Press, 2008.

Thompson, Robert. Defeating Communist Insurgency: The Lessons of Malaya and Vietnam. 1966.

Trinquier, Roger. Modern Warfare: A French View of Counterinsurgency. London: Pall Mall Press, 1964.

Warde, Ibrahim. The Price of Fear. University of California Press, Los Angeles, CA. 2007. 172.

Weinberg, Leonard. Global Terrorism. Oxford: Oneworld Publications, 2005. 